\title{
Editorial
}

\section{Partnerships in Employment}

\section{Introduction}

It is indeed a pleasure to see this issue of the Journal hosting a series of states' progress in the Employment First initiative led by the University of MassachusettsBoston Institute for Community Inclusion. Dr. John Butterworth has provided tenacious leadership with highly driven colleagues to develop and maintain the Employment First Initiative. Dr. Julie Christensen first opened up this discussion with me on having a special issue almost 2 years ago and along with John and Karen Flippo, a dedicated employment pioneer and advocate, this issue emerged.

Numerous states, most at differing levels of progress, report in their own words how Employment First is transpiring in their states. This special issue demonstrates the efforts of different states in the Midwest such as Iowa, Wisconsin, and Missouri to Alaska and California in the West as well as Mississippi and Tennessee in the South and New York in the East. Additionally, there is a paper on evaluation from the Lewin group that helps shape the context of these state efforts.

A major reason we wanted to publish this material is to let the APSE membership know how supported employment (Wehman, Chan, Ditchman, \& Kang, 2014) and customized employment (Riesen, Morgan, \& Griffin, 2014), as well as employer development strategies, are being used in the Employment First Initiative and especially how lives of persons with disabilities and their families are being transformed. One must ask: If these states can do it, then why can't others? What are they doing that other states need to be doing? And how long must this generation wait to become competitively employed and be paid for their work as well as receive the dignity of holding a real job? This country can and should do better by its citizens with disabilities and Employment First has become a major means for this to happen (Butterworth, Hiersteiner, Engler, Bershadsky, \& Bradley, 2015).
As I reviewed each of these papers, I thought about the potential ripple effect from their efforts to others. I wondered about how many people, agencies and the general statewide community have been or could be further impacted. These thoughts have lead me to suggest some indicators that could be used to evaluate the system change that is steadily occurring because of the Employment First effort.

\subsection{Measuring systems change in employment programs}

For clients with significant disabilities who have been chronically unemployed, it is usually difficult to see rapid change in the programs that are charged with providing these clients competitive integrated employment. As these programs move from centerbased activities to community-based employment, change, if it happens at all, is very subtle initially. It can take several years for these changes to occur because of the deeply entrenched policies and practices (Freeze et al., 2007). It is important to realize that the existing segregated models have been in place, in many cases, for over half a century and changing them to ones of inclusion overnight will not be easy (Sulewski et al., 2017). It is also clear from looking at previous efforts at downsizing Centers and conversion that change can and does occur through persistent efforts to provide competitive integrated employment. Whichever employment model is utilized, systems will invariably begin to show change in many, many ways because competitive employment is transformative. However, unless one knows what variables to look for, it is hard to see these emerging aspects of a system beginning to change.

We identify below, a number of indicators that might be examined in this journey from segregation to integration. These are indicators, which span many aspects of the community, not only the program, and are suggestions for how to best inform our thinking about the ripple effects of competitive integrated 
employment. Some of these variables can be measured quantitatively and others will require more of an interviewing approach.

\section{Clients:}

- Do the clients in the pool selected for job placement respond favorably or unfavorably when approached about employment?

- Are there an increasing number of clients being placed into competitive employment?

- Do other clients, who are not in the pool of people to be placed in the Center, begin to indicate interest in employment?

- Do clients who are working talk enthusiastically about their job?

- Do clients who are working want to work more or even have a second job?

- Do clients have an increasingly greater voice in what job they want, what work conditions and who should support them?

- Do clients who are working have more community experiences and friendships?

- Do clients who are working competitively attend business social activities when not at work?

- Do clients who are working show skill development in other areas such as talking, money management, personal care and other related skills?

- Do clients who are employed show interest in RETURNING TO WORK at the center?

\section{Families:}

- Do families of clients working show increased enthusiasm and support of their child working?

- Do families of clients working provide more support in helping their child get to and from work, hygiene, money, etc.?

- Do families of clients waiting for employment help with job development?

- Do parents who were negative about employment become less negative?

- Do families of clients who are working talk to other families about their child's experience?

\section{Community:}

- Are there newspaper articles that describe these work experiences of clients?

- Are there TV or radio or social media coverage of work experiences and what is the reaction?

- Do customers of companies employing clients respond favorably to clients working there?

\section{Employers:}

- Do employers become satisfied and engaged with the employment support they receive?

- Do employers want to hire persons with disabilities again?

- Are employers willing to talk to other employers about their clients and be advocates for them being hired?

- Are coworkers in the company supportive and in what ways?

- Will coworkers speak in the community or other public forums to discuss the competence of their workers with disabilities?

\section{Programs}

- Does the staff in the Center show increasing verbal support as the new employment program is initiated?

- Does staff get excited when a new placement is made?

- Does staff pay attention to the amount of hours and/or quality of job the client is receiving?

- Does the Center begin to increase resources and expand the time to train staff in employment support programs?

- Does staff in the Center who do not like the move toward employment programs resign and are they replaced with staff more supportive of competitive employment as an outcome?

- Does staff in the program who are not directly involved ask more questions and show interest?

- Does the program management begin to realign more resources into employment support programs that center based programs and how is this done?

- Does the program Board of Directors show increased interest in competitive integrated employment?

- Does the program center begin to consider a strategic plan that would reduce physical size of facility and put more resources into employment support labor?

- What is in the strategic plan for change in center and what is the timeline?

- Are there specific celebrations or graduations highlighting the employment successes of clients and former clients?

- Do programs develop formal relationships and partnerships with businesses in meeting with local Chambers of Commerce or trade associations? 


\section{Local and State Agencies:}

- Does state vocational rehabilitation begin to expand the number of referrals to the program for competitive employment?

- Are there more competitive employment (Status 26) closures?

- Is there greater communication and partnering between program staff and VR counselors about work?

- Is there a greater level of communication between local high schools and program staff about job placement?

- Does high school staff invite program staff to their classes to see potential clients and assess their employment capacity?

- Do state agencies begin to create collaborative written partnerships that have money and intellectual resources behind each of the commitments?

- Do state agencies begin to create collaborative written partnerships and timelines on the number of persons placed (not just served) and maintained in competitive employment?

- Do state agencies begin to pay and/or share funding for competitive employment outcomes and influence centers to realign their resources?

- Do local centers and local community service funding agencies create partnerships that generate shared funding resources for employment outcomes?

- Do local center staff have a seat at the table for transition, work force center and other

\section{VR and Medicaid Waiver Initiatives:}

- Do agencies change the language in requests for federal dollars, such as Medicare waiver applications, to create a mechanism for money following the client's competitive employment outcomes?

\subsection{Final thoughts}

We think this issue will be a special one indeed, as it will be the first published series of papers dedicated to learning about the progress of a number of Employment First states. This special issue reflects the direction of the U.S. Department of Justice in closing sheltered workshops (U.S. Department of Justice, 2011; United States vs. State of Rhode Island, 2014). It is our hope and goal that these papers will motivate others to submit comparable papers about the experiences in their states. As positive change occurs, we must get this information out to everyone working in the field of Vocational Rehabilitation.

Paul Wehman, Ph.D. Editor-in-Chief

\section{References}

Butterworth, J., Hiersteiner, D., Engler, J., Bershadsky, J., \& Bradley, V. (2015). National Core Indicators: Data on the current state of employment of adults with IDD and suggestions for policy development. Journal of Vocational Rehabilitation, 42(3), 209-220.

Freeze, S., Hall, A., Collins, S., Shumate, D., Thomas, C., \& Brent, B. (2017). Different states, common issues: Moving mountains one service at a time. Journal of Vocational Rehabilitation, 46(3), 265-271. doi:103233JVR-170861

Riesen, T., Morgan, R., \& Griffin, C. (2015). Customized employment: A review of the literature. Journal of Vocational Rehabilitation, 43(3), 183-193.

Sulewski, J., Timmons, J., Lyons, O., Lucas, J., Vogt, T., \& Bachmeyer. K. (2017). Organizational transformation to integrated employment and community life engagement. Journal of Vocational Rehabilitation, 46(3), 313-320. doi:10.3233JVR170867

U.S. Department of Justice. (2011). Statement of the Department of Justice on enforcement of the integration mandate of Title II of the Americans with Disabilities Act and Olmstead v. L.C. Retrieved from http://www.ada.gov/olmstead/ q\&a_olmstead.htm

United States vs. State of Rhode Island (2014). Retrieved from http://www.ada.gov/olmstead/documents/ri-olmsteadstatewide-agreement.pdf

Wehman, P., Chan, F., Ditchman, N., \& Kang, H. J. (2014). Effect of supported employment on vocational rehabilitation outcomes of transition-age youth with intellectual and developmental disabilities: A case control study. Intellectual and Development Disabilities, 52(4), 296-310. 